\title{
BABANKI VERB TONE
}

\author{
Pius W. Akumbu \\ University of Buea, Cameroon
}

\begin{abstract}
In Babanki ${ }^{1}$, a Grassfields Bantu language of northwestern Cameroon, several tonal patterns can be found on a single verb root depending on the construction in which the verb is used. An underlying high tone may surface normally as high, but unexpectedly as low, or high-falling; while underlying low tones surface as high, high-falling, or normally as low. For this reason the low tone verb can have a $\mathrm{L}(\mathrm{L}), \mathrm{HL}$, or even $\mathrm{H}(\mathrm{H})$ surface melody while the high tone verbs can be $\mathrm{L}(\mathrm{H}), \mathrm{HL}$, or $\mathrm{H}(\mathrm{H})$. Accounting for these melodies in order to reconstruct the underlying forms is necessary for a proper understanding of the Babanki verb tone in particular and the tonal system of Centre Ring Grassfields Bantu languages in general. This paper demonstrates that five tone rules (Downstep, Tone Docking, High Tone Spread, Low Tone Spread, and Upstep) and one phonological rule (Schwa Insertion) are required to account for the complex tonal system of Babanki verbs.
\end{abstract}

Keywords: Babanki, Bantu, tone, morphology

\section{Introduction}

This paper ${ }^{2}$ accounts for the numerous surface tonal melodies found on the verb in Babanki, a Grassfields Bantu language of northwestern Cameroon. An examination of the verb system reveals that, depending on the construction type, up to three tonal patterns may be found on both low and high tone verbs (See $\$ 3.3$ where it is shown that Babanki verbs have two lexical tones: high and low). An underlying high tone may surface normally as high, but unexpectedly as low, or falling while underlying low tones surface as high, falling, but normally as low. For this reason the low tone verb can have a $\mathrm{L}(\mathrm{L}), \mathrm{HL}$, or even $\mathrm{H}(\mathrm{H})$ surface melody while the high tone verbs can be $\mathrm{L}(\mathrm{H}), \mathrm{HL}$, or $\mathrm{H}(\mathrm{H})$. Sometimes, a high tone can be downstepped while a low tone can undergo upstep. Accounting for these melodies in order to reconstruct the underlying forms is necessary for a proper understanding of Babanki verb tone in particular and the tonal system of Centre Ring Grassfields Bantu languages in general. This is so because most of the work on tone in Babanki has focused on the nominal system (Hyman 1979, 1980; Akumbu 2011). A treatment of verb tone will therefore provide a more complete picture of Babanki tone and also lay the groundwork for

1 Babanki (Kejom, as the native speakers call their language and villages), is spoken in Babanki Tungo (Kejom Ketinguh) and Big Babanki (Kejom Keku) in the North West Region of Cameroon by approximately 39,000 people (Ethnologue, 2015). As a Babanki native speaker I have provided the data used in this paper but also checked with two other native speakers, Nico Wukeh (41-year old male) and Regina Phubong (68-year old female), to confirm the phonetic level of each construction.

2 Thanks to Larry Hyman, Shigeki Kaji, and Ngessimo Mutaka for their comments on this paper. I also gratefully acknowledge the opportunity I had to work on this paper when I was invited to the Graduate School of Asian and African Area Studies (ASAFAS), Kyoto University as a Visiting Research Scholar from July 1 to October 31, 2013. 
analyzing the tone systems of the other languages in the group. This paper demonstrates that five tone rules (Downstep, Tone Docking, High Tone Spread, Low Tone Spread, and Upstep) and one segmental rule (Schwa Insertion) are necessary to account for the apparently complex tonal system of Babanki verbs. The theoretical frameworks used in the analyses are Register Tier Theory (RTT) and Autosegmental Phonology (AP). This paper is structured as follows: An overview of RTT is given in $\S 2$ and the Babanki verb system is introduced in $\S 3$ while $\S 4$ contains a presentation of tense, aspect and mood. The phonological processes that are recurrent in the verb system are discussed in $\S 5$. An expansion of the discussion to verbal reduplication is found in $\S 6$, which is followed by a conclusion.

\section{An overview of register tier theory}

Register Tier Theory (RTT) (Inkelas 1987; Inkelas et al. 1987; Snider 1988, 1990, 1999; Akumbu 2011) recognizes the following autosegmental features and tiers: the register features $h$ and $l$ on a REGISTER TIER, the tonal features $\mathrm{H}$ and $\mathrm{L}$ on a TONAL TIER, a TONAL ROOT NODE TIER (TRN), and a TONE-BEARING UNIT TIER (TBU). These tiers are geometrically arranged according to the configuration in Figure 1 taken from Snider (1999: 23).

Figure 1: Geometry of tone

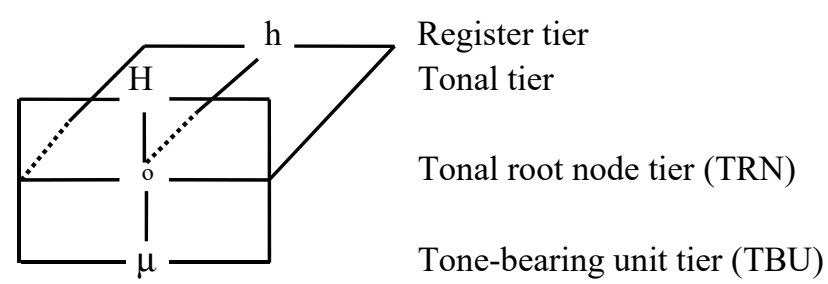

Features on the Register tier and the Tonal tier are linked to structural nodes on the TRN. Geometrically, these tiers form a separate plane with respect to the TRN. Nodes on the TRN are, in turn, linked to moras $(\mu)$ on the TBU tier (Snider 1999: 23).

The register features $\mathrm{h}$ and $\mathrm{l}$ are defined following Snider (1999: 25) as "effect a register shift $\mathrm{h}=$ higher, and $\mathrm{l}=$ lower relative to the preceding register setting", and the tonal features $\mathrm{H}$ and $\mathrm{L}$ are defined as realize the "TBU at $\mathrm{H}=$ high pitch, and $\mathrm{L}=$ low pitch relative to the current register." This is shown in Figure 2 (the dotted lines represent registers and the solid lines represent tones).

Figure 2: Register features and tonal features

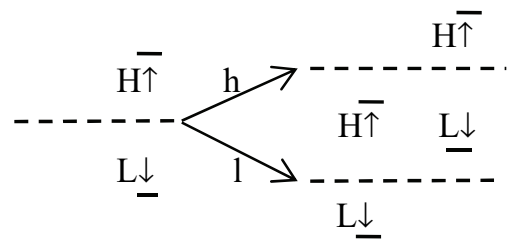


The geometry in Figure 1 and the features in Figure 2 make it possible to specify up to four logically possible tonal distinctions, namely, a high tone on a high register, a high tone on a low register, a low tone on a high register, and a low tone on a low register. The register feature of any given TBU is specified in relation to that of the preceding register. The register of the initial TBU for its part is construed to be higher than or lower than the reference point that native speakers usually have in mind when beginning an utterance. Secondly, the tonal feature associated to any given TBU specifies whether the tone is low or high in relation to the current register. RTT is used in this paper to insightfully explain the tonal processes, given that within this theoretical model features on each tier can behave independently of one another.

\section{The verb}

In this section the structure of the Babanki verb is shown. The section comprises a presentation of the verb root, verbal extensions, and tone groups, which are relevant to the discussion of verb tone in the language.

3.1. Verb root. According to Akumbu \& Fogwe (2012) only one-syllable roots are attested in Babanki except when there is verbal reduplication. The verb roots that appear to have two syllables always have a CV ending, which can be interpreted as an extension (see §3.2).

Nevertheless, there are formal extensions that can be considered part of the root. Examples of the two verb root types are given below.

(1) Verb root types

\begin{tabular}{|c|c|c|c|}
\hline \multicolumn{2}{|c|}{ One-syllable } & \multicolumn{2}{|c|}{ Two-syllable } \\
\hline sày & 'dry' & djìsà & 'make a fire' \\
\hline$t \int \grave{o}$ & 'pass' & bàylà & 'dodge' \\
\hline$v \grave{~}$ & 'come' & fis̀̀ & 'remove' \\
\hline$d i$ & 'cry' & nàylà & 'tickle' \\
\hline kám & 'squeeze' & báyká & 'show pride' \\
\hline búm & 'hunt' & tóytá & 'sift' \\
\hline făy & 'fall' & fáptá & 'hurry up' \\
\hline kwén & 'enter' & bútsá & 'ignore' \\
\hline
\end{tabular}

The one-syllable roots can have either a CV or CVC structure whereas the two-syllable roots have a $\mathrm{CV}(\mathrm{C}) \mathrm{CV}$ structure. It can also be seen in the data above that the second of the two-syllable roots is always of the $\mathrm{CV}$ type, and that the $\mathrm{V}$ is always schwa. There are a good number of such roots that cannot stand alone without the second $\mathrm{CV}$ syllable, which is referred to in this paper as a "formal extension".

In addition to these, there are two-syllable roots with a different structure. In this set, the second syllable begins with a glottal stop, followed by a vowel identical to that of the first syllable. This vowel has been referred to as an echo vowel (Akumbu \& Fogwe, 2012). 
(2) Echo Vowels

$\begin{array}{ll}\text { Echo Vowel Stem } & \text { Gloss } \\ \text { mà?à } & \text { 'throw' } \\ \text { tà?à } & \text { 'become stiff' } \\ \text { bjèrè } & \text { 'carry' } \\ \text { fìí } & \text { 'descend' } \\ \text { mjàṙ̀ } & \text { 'blink' } \\ \text { bjî’í } & \text { 'fold' }\end{array}$

3.2. Extensions. The majority of what looks like two-syllable verbs results from the addition of a verbal suffix or extension ${ }^{3}$ to the root. At least five kinds of extensions are commonly found on verb roots, as illustrated below. A more extensive discussion of Babanki extensions can be found in Hyman (2013).

3 Verbal extensions in Babanki fall short of what is typical of Narrow Bantu in that there are no affixes for all extensions such as 'applicative', 'passive', 'middle' (impositive), etc., and most of these functions, where present at all, are based on combinations of autonomous lexical items. The common extensions are morphemes for 'attenuative', 'intensity', and 'repetitive', with different forms for the latter based on whether the verb is transitive or not. 
(3) Verb extensions

\begin{tabular}{|c|c|c|c|c|}
\hline -so & -kə & $-\mathbf{t o}$ & -la & -mo \\
\hline 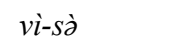 & $b v \grave{i}-k \grave{\partial}$ & 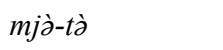 & kò-là & kwò?-mà \\
\hline 'bring near' & 'fail repeatedly' & 'complete' & 'scrape many times' & 'think together' \\
\hline kùm-sà & djàn-kj̀ & $b \grave{a})_{-} t \grave{\partial}$ & dày-là & sù-mà \\
\hline 'touch' & 'protrude' & 'scrape' & 'spread' & 'persist continually' \\
\hline $\int \hat{l}-s \grave{~}$ & $t \int \grave{o}-k \grave{\partial}$ & bùm-tò & sì-là & $t \int \hat{o}-m \grave{\partial}$ \\
\hline 'remove' & 'pass repeatedly' & 'meet someone' & 'caress many times' & 'pass again and again' \\
\hline kwén-sá & fáy-ká & bá?-tá & kán-lá & pfwó-má \\
\hline 'send inside' & 'fall repeatedly' & 'arrange/plan' & 'fry in part' & 'return' \\
\hline bén-sá & ká?-ká & té-tá & té-lá & fáy-má \\
\hline 'make dance' & 'turn around' & 'select' & 'insult many times' & 'gather several things' \\
\hline bwóm-sá & $b w i-k a ́$ & níy-tá & fár-lá & kjé-má \\
\hline 'praise' & 'give birth a lot' & 'run hurriedly' & 'pin many times' & 'allow to fall' \\
\hline
\end{tabular}

3.3. Tone groups. It is necessary to examine the infinitive or imperative verb forms of Babanki in order to determine which tone group a verb belongs to. Consider the following forms for illustration.

Table 1: Infinitive and imperative verb forms

\begin{tabular}{|c|c|c|c|}
\hline Infinitive & Imperative & Infinitive & Imperative \\
\hline a-fü? 'to bubble' & fùrá 'bubble' & $a^{\downarrow}{ }^{\downarrow} f u ́$ ? ' to tune' & fú? 'tune' \\
\hline á-dàm 'to grunt' & dàmá 'grunt' & á-dám 'to play' & dám 'play' \\
\hline á-mò 'to narrate' & mòá 'narrate' & 'to deny' & $m o ́ ~ ' d e n y '$ \\
\hline
\end{tabular}

In the infinitive form, all verb roots surface with a low tone or a downstepped high tone while in the imperative, they are either low-high or high. An account of downstep is given in $\S 5.1$. Therefore the two verb groups that can be identified in Babanki based on their tones are Low and High as illustrated in (4). 
(4) Verb tone groups

Low tone verbs

fù? 'bubble'
dàm 'grunt'
fàs 'break'
zwì 'pant'
mò 'narrate'
kjè 'scrape'
sò? 'seize'
mjàtà 'complete'
fis̀̀ 'remove'

High tone verbs

fúp 'tune'
dám 'play'
fás 'threaten'
zwi 'kill'
mó 'deny'
kjé 'allow'
só? 'judge'
bínsá 'lure to sleep'
yóssá 'open a little'

One-syllable verb roots are more common than those with two syllables.

\section{Overview of tense, aspect, and mood}

Babanki has an eight-way temporal distinction with four past tenses (immediate (P1), hordienal $(\mathrm{P} 2)$, distant (P3), and remote (P4)), a present tense (P0), and three future tenses (immediate (F1), hordienal (F2), and remote (F3)).

A distinction can be made between perfective and imperfective aspect in Babanki. The imperfective aspect markers commonly used in the language are the progressive and habitual. When there is no explicit reference to the internal temporal constituency of a situation, it is understood as being perfective. In other words a construction with perfective aspect presents an event as a time-bounded whole, without regard to the internal constituency of that event. This aspect is marked by a floating low tone found before the verb root.

The Babanki verb system employs several moods to indicate the speaker's attitude toward the factuality or likelihood of the action or condition expressed. The declarative, imperative, and potential are among the mood distinctions made in the language. A detailed discussion of Babanki tense, aspect, and mood can be found in Akumbu \& Fogwe (2012). In the table that follows the affirmative, negative, progressive, and imperative forms are given for all tenses. The glosses have all been given only in the affirmative for clarity of presentation. Each gloss could be rendered in the negative, progressive and imperative form as needed. 
Table 2: Tense, mood, aspect distinctions in Babanki

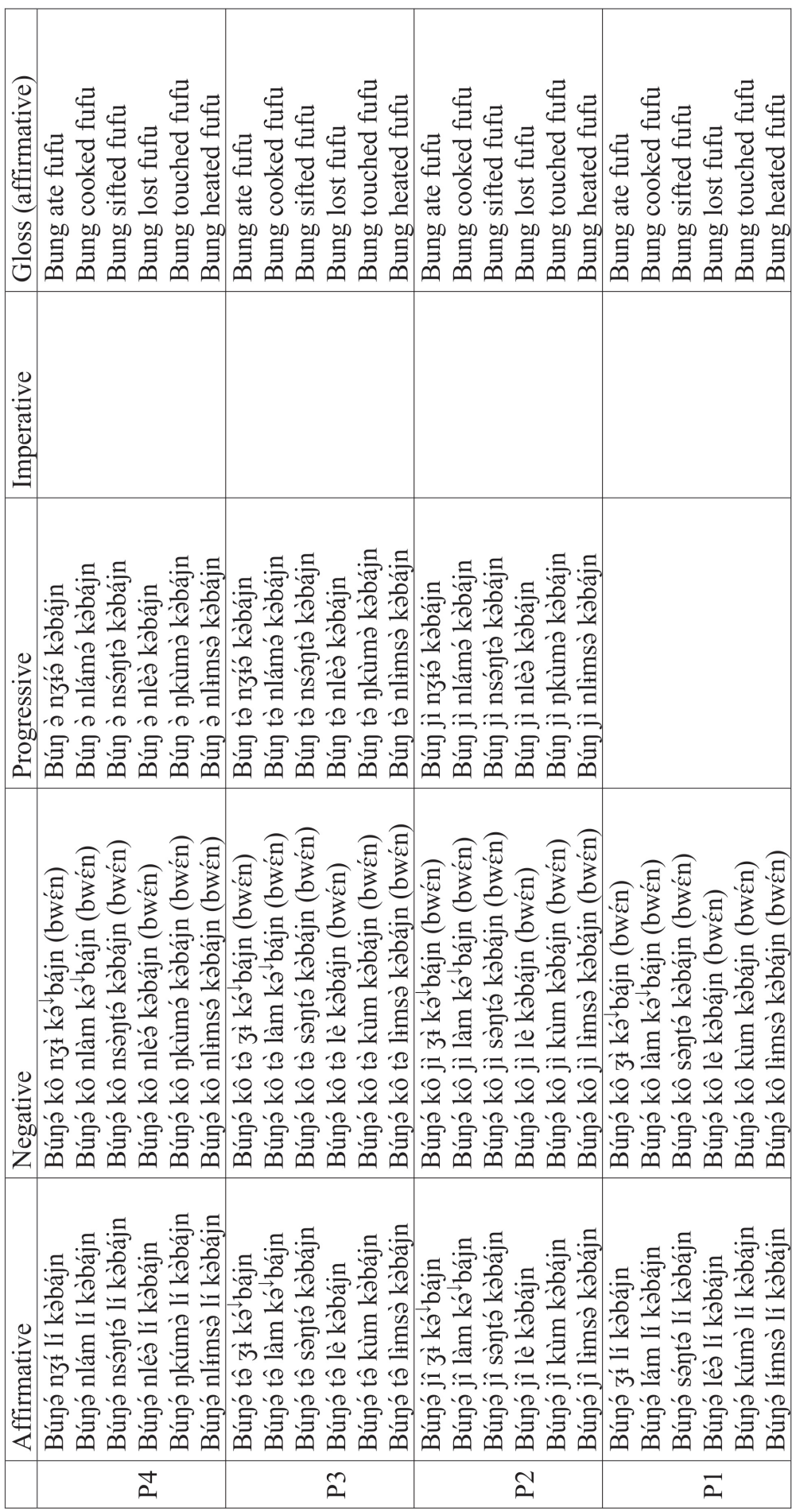




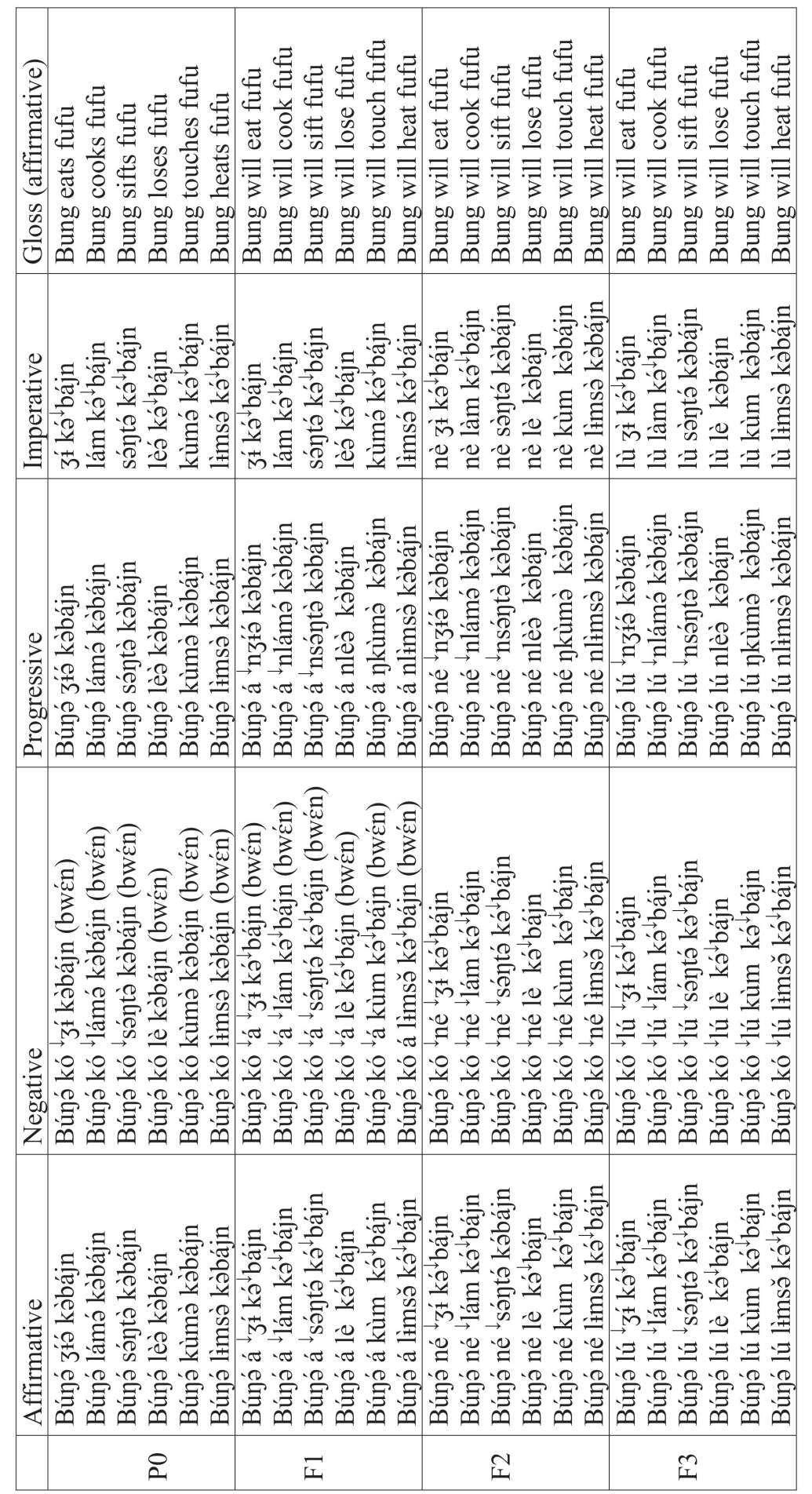




\section{Verb tone}

5.1. Downstep. Downstep is commonly used to describe the overall 'downtrend' of pitch in tone languages. Scholars have referred to the phenomenon using different terminologies and Connell (2001) distinguishes between downdrift, downstep, and declination. In this paper downstep is used to refer only to the situation where the second of two high tones in a sequence is realized at a lower level than the first.

In Table 2, one instance where downstep occurs is between the high tone of future tense markers and the immediately following high tone of the verb root (see F1, F2, and F3). In this case, downstep is motivated by the fact that the future tense markers consist of a high tone morpheme plus a final floating low tone as follows: $a$ ' 'F1', né 'F2', and lu' 'F3'. In these constructions, the low tone remains floating and rather spreads its low register feature to the following high tone. This is followed by the delinking of that tone's high register such that the high tone of the verb root is realized on a lower register than the preceding high tone of the tense marker.

The same process also occurs in present and future tense negative forms (P0, F1, F2, F3, F4). The floating low tone of the discontinuous negation marker kó ' ... bwen behaves in a similar manner, causing downstep of the following high tone. The indication of repeated downstep in the negative future forms shows that the high tones of the tense marker and verb root are downstepped relative to that of the negation marker.

This kind of downstep caused by a floating low tone is commonly known in the literature as non-automatic downstep (Snider 1999) and formalized here in RTT terms as follows.

(5) Downstep

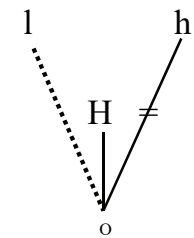

According to this rule, a floating low register feature spreads rightward, and, in a subsequent process, delinks the following high register feature, causing the high tone to be realized on a lower register (downstep), illustrated in the following derivation. In this and other derivations in this paper, the arrows next to the register features illustrate the shift in register, $1 \searrow=$ downward and $\mathrm{h} \nearrow=$ upward. 
Figure 3: Downstep

Input

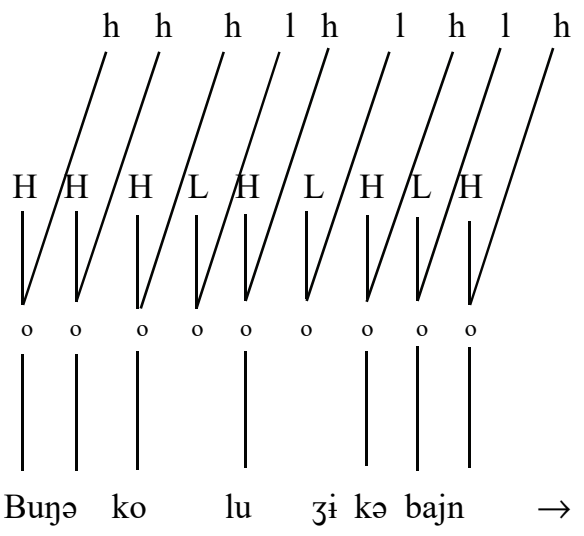

Other rules (HTS, Merger, Stray Erasure)

\section{Downstep}

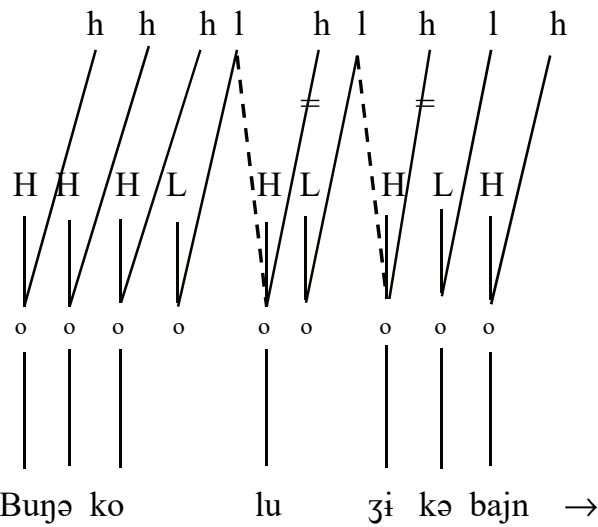

Phonetic Representation

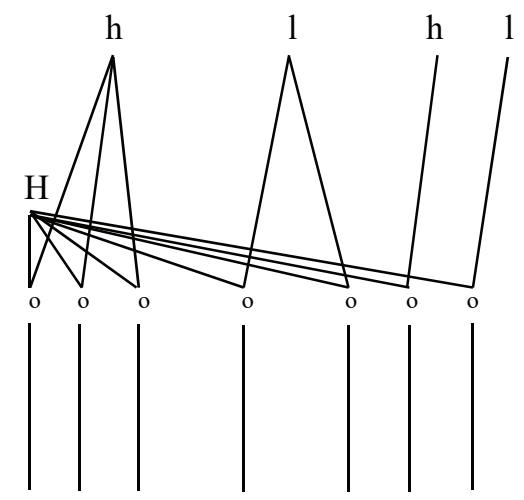

Buyə ko lu zi kə bajn

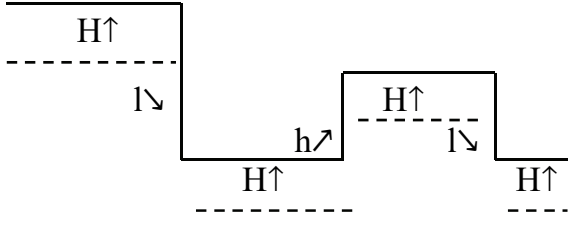

Búyó kó $\quad \downarrow^{\downarrow} \mathfrak{l u ́}^{\downarrow}$ zí kó $\quad$ bájn

After $l$ spread and $h$ delink that result in a downstep, HTS (discussed in $§ 5.3$ ) causes the high tone of the verb [3i] to spread to the prefix of the following noun such that the prefix which has a low tone underlyingly surfaces on a high tone. Merger then coalesces identical adjacent features and stray erasure deletes all unassociated (i.e., floating) elements. The last diagram in the derivation shows that the first three high tones are realized on a high register after which there is a register shift downwards such that the fourth and fifth high tones are realized on a low register. The register again moves upward and the sixth high tone is realized on a high register. Finally, the register is lowered and the last high tone is realized on a low register.

Downstep of the noun root high tone is explained in $\$ 5.4$. Further evidence for downstep is provided by infinitive forms in the language. Akumbu \& Fogwe (2012) argue that the infinitive is marked by a high tone schwa but downstep provides evidence for the modification of that claim. It shows that in addition to the high tone schwa there is a floating low tone at the end of infinitive forms ( $\left.\dot{a}^{\prime}\right)$. When the high tone schwa and the floating low tone combine with low tone roots (6a), the floating tone merges with the low tone of the root but if they are attached to high tone verb 
roots (6b), the floating low tone causes the high tone of the verb to be realized at a lower level than the infinitive high tone.

\begin{tabular}{|c|c|c|c|c|c|}
\hline (6) a. á-kù & [ə́-kù] & 'to snore' & b. á-kú & {$\left[{ }^{\prime}-{ }^{\downarrow} \mathrm{kú}\right]$} & 'to give' \\
\hline$a ́-m o ̀$ & [ó-mò] & 'to narrate' & à-mó & {$\left[\partial{ }^{\downarrow}{ }^{\downarrow} \mathrm{mó}\right]$} & 'to deny' \\
\hline á-sàm & [ó-sàm] & 'to swim' & à-sám & [ó-`sám] & 'to migrate' \\
\hline á-bò̀tà & [ó-bò?tว̀] & 'to open' & à-bóPsá & [ó-'bó?sá] & 'to join' \\
\hline à-fisà & 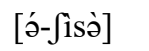 & 'to remove' & à-fîsá & 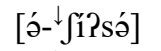 & 'to put down' \\
\hline á-bàylà & [ว́-bàylò] & 'to pretend' & à-lántá & [ó-`lántó] & 'to bend down' \\
\hline
\end{tabular}

Wherever a verb is used in the infinitive form, downstep occurs as shown in (7).

(7) a. átfò fá ygày 'to pass through the residence'

à kú? á fảkj̀? 'to climb on a tree'

b. wù jì tfồn átfò 'you refused to pass'

wù jì tfòn á ${ }^{\downarrow} k u ́$ ? 'you refused to climb'

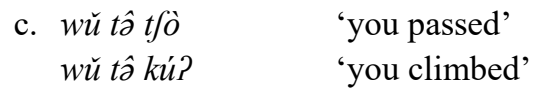

The data in (7a and b) show that there is always downstep of the high tone of the root when the infinitive form of the verb is used. This is confirmed by the forms in (7c) where there is no infinitive marker and no downstep. High tone infinitive verbs can be derived as in Figure 4.

Figure 4: Downstep in infinitives

$$
\text { Input }
$$

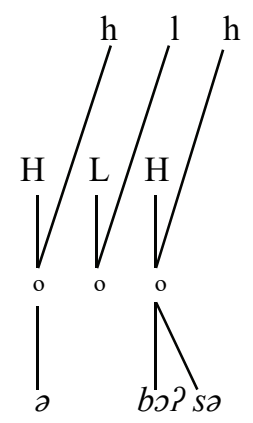

Downstep and Stray Erasure

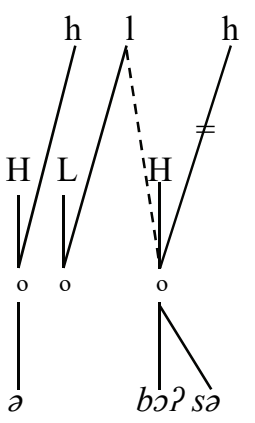

Phonetic Representation

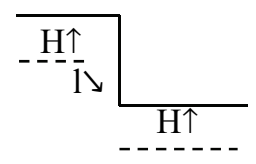

á - \bó?sá 
The derivation shows that the floating low register feature of the infinitive spreads to and delinks the following high register feature of the root high tone causing it to be realized on a low register.

5.2. Tone docking (TD). Underlying floating tones dock leftward in at least the negative, imperative and imperfective forms, while tone docking to the right occurs in the imperative and imperfective. It has been mentioned above that the floating low negation tone causes downstep of the following high tone. This happens only when the low tone fails to dock leftward in future tense constructions. Generally, the floating negation tone docks leftward onto the first negation morpheme, as shown in the following data.

(8) a. Búyá kô zì kả bájn (bwén)

Bún á kó zú kà.bájn bwعn ${ }^{4}$

Bung SM NEG eat C7.fufu NEG

'Bung has not eaten fufu.'

b. Búgá kô jì ż̀ ká bájn (bwén)

$\begin{array}{lllll}\text { Bún ó kó ' jì źl kò.bájn } & \text { bwen } \\ \text { Bung SM NEG } & \text { P2 } & \text { sift C7.fufu } & \text { NEG } \\ \text { 'Bung did not eat fufu.' }\end{array}$

c. Búyá kô tà ż̀ ká bájn (bwén)

Bún á kó tò zí kò.bájn bwen

Bung SM NEG P3 sift C7.fufu NEG

'Bung did not eat fufu.'

d. Búyá kô nż̀ kả bájn (bwén)

$\begin{array}{lllll}\text { Bún ó kó } & \mathrm{N}^{5} \text {-zá } & \text { kò.bájn } & \text { bwen } \\ \text { Bung SM NEG } & \text { N-eat } & \text { C7.fufu } & \text { NEG } \\ \text { 'Bung did not eat fufu.' } & & \end{array}$

The examples illustrate that in all past tenses, the first negation morpheme is high-falling due to the leftward docking of the floating low tone. Tone docking is formalised in autosegmental terms as follows:

4 bwcn 'NEG' has been represented underlyingly without a tone mark because it seems that it can be realized on either a high or a low tone. What determines the choice is not clear yet and remains a point to be investigated.

5 The nasal has simply been glossed ' $\mathrm{N}$ ' because its origin and function remain unclear not only in Babanki but also in Kom (Shultz, 1997) and Bafut (Tamanji, 2009) where it has been analysed as induced by the verb or as an aspect marker respectively. 
(9) Tone Docking

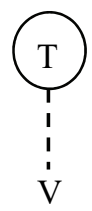

According to this rule a floating tone docks onto a TBU which may be either to the left or right. In (8), docking is leftward and results in a contour tone, as shown in the following derivation.

\begin{tabular}{|c|c|c|}
\hline & 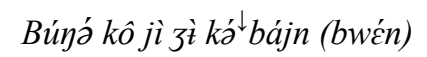 & Búyá kô nż̀ kábbájn (bwćn) \\
\hline nput & /Búy á kó jì̀ zá kàbájn bwen & Búy á kó N-zí kòbájn bwen/ \\
\hline & Bún á kô jì zł́ kàbájn bwen & Búy á kô N-ź́ kàbájn bwen \\
\hline 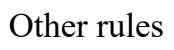 & Búyó kô jì zì ká bájn bwén & Búná kô nzì ká bájn bwén \\
\hline & [Búná kô jì jì kábbájn (bwén) & Búqá kô nzì kábbájn (bwén)] \\
\hline
\end{tabular}

Imperative (IMP) forms also undergo tone docking albeit bidirectionally. IMP is marked by a floating high tone found immediately after the verb root. It docks leftward to form a LH melody when the verb tone is low or merges with the high tone if the verb tone is high. ${ }^{6}$ At the same time, docking occurs to the right on condition that the following noun has a class marker (prefix). The following data show TD in the imperative when the subject is singular.

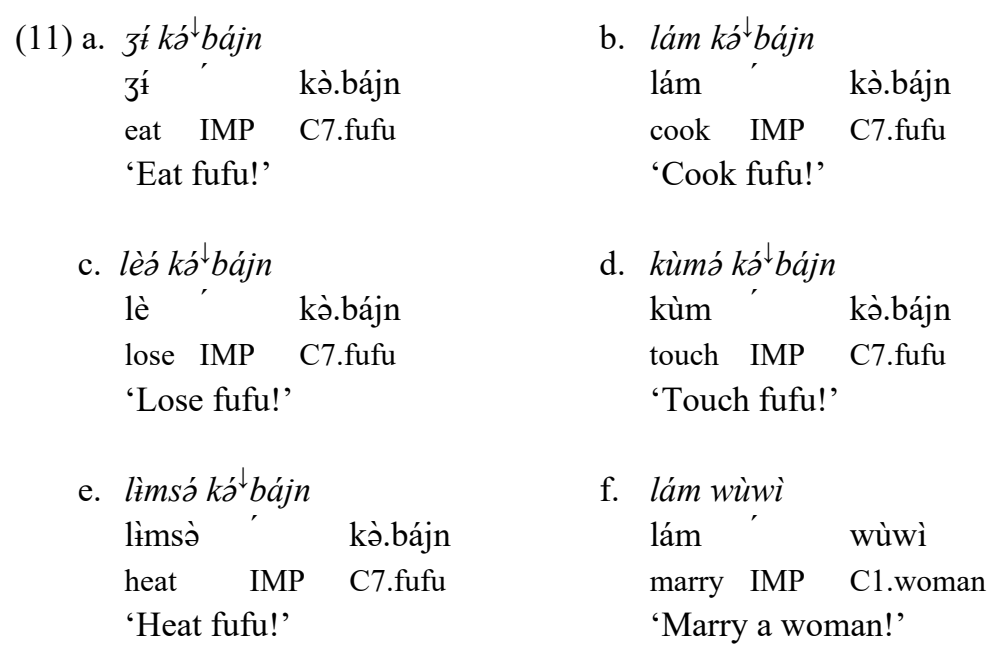

${ }^{6}$ A similar situation is reported in another Northwestern Grassfields language, Moghamo, where the imperative marker is also a floating high tone that associates in various ways depending on the verb stem (Achiri-Taboh, 2013). 


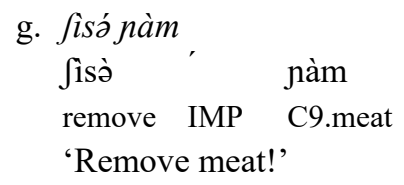

The IMP high tone consistently docks leftward onto the verb but docks rightward only onto noun class prefixes. The examples in (11c and d) show that when low tone verb roots have only one syllable a schwa is inserted to bear the imperative tone (discussed in §5.5) and avoid a rising tone on a single TBU. (11e and g) show that the floating imperative high tone replaces the low tone of the second syllable of two-syllable low tone roots. In (11f and g) the IMP tone does not dock rightward because the nouns do not have prefixes. Imperative forms are derived as follows:

\begin{tabular}{|c|c|c|}
\hline & lám kảbbájn & lìmsá kà bájn \\
\hline nput & Mám 'kòbájn & lìmsò ' kə̀bájn/ \\
\hline D & lám kâbájn & lìmsă kâbájn \\
\hline les & lám kábájn & lìmsá ká bájn \\
\hline $\mathrm{R}$ & [lám ká bájn & lìmsá ká bájn] \\
\hline
\end{tabular}

Future affirmative and negative (imperfective) constructions also undergo TD, as illustrated by the following F2 forms. Notice that there is a floating high tone after the verb root that marks imperfective $^{7}$ (IPF) aspect.

(13) a. Búyá né lám kádbájn

Bún ó né lám ' kə̀.bájn

Bung SMF2 cook IPFC7.fufu

'Bung will cook fufu.'

c. Búyá né kùm kábájn

Bún ó né kùm ' kò.bájn

Bung SMF2 touch IPFC7.fufu

'Bung will touch fufu.'

e. Búgá né lìmsă ká bájn

Bún á né lìmsà ' kà.bájn

Bung SMF2 heat IPFC7.fufu

'Bung will heat fufu.'

g. Búyá kó `né kùmsă ká bájn

Bún á kó né kùm-sò

kə̀.bájn

Bung SMNEG F2 touch-EXT IPF C7.fufu

'Bung will not touch fufu.'

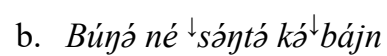

Bún á né sájtá kà.bájn

Bung SMF2 sift IPFC7.fufu

'Bung will sift fufu.'

d. Búgá né kùmsă ká bájn

Búy á né kùm-sò ' kò.bájn

Bung SMF2 touch-EXT IPF C7.fufu

'Bung will touch fufu.'

f. Búyá kó ${ }^{\downarrow}$ né kùm kàbájn

Búy á kó 'né kùm ' kò.bájn

Bung SMNEG F2 touch IPFC7.fufu

'Bung will not touch fufu.'

h. Búyá kó ${ }^{\downarrow}$ né lìmsă kà bájn

Bún á kó né 'lìmsà ' kà.bájn

Bung SMNEG F2 heat IPF C7.fufu

'Bung will not heat fufu.'

7 Imperfective aspect is used in Babanki to represent events as occurring "over a longer or undefined period" (Nurse, 2003). 
The floating IPF high tone, like the imperative high tone, also docks both leftward and rightward. Two-syllable low tone verbs surface with LH on the second syllable (13d, e, g and h), providing support for leftward docking whereas one-syllable low tone verbs show no trace of the floating high tone on the verb (13c and $\mathrm{f}$ ) suggesting that the IPF tone docks only if the preceding verb has an extension attached to it. A comparison of (13f and $\mathrm{g}$ ) in particular reveals that leftward docking of the IPF tone occurs only if the verb takes an extension. The fact that the following noun prefix also surfaces on a high tone shows that the floating IPF tone also docks rightward. The way the verb root and the following object relate is discussed briefly in $§ 6.4$.

5.3. High tone spread (HTS). High tone spread is also common in the Babanki verb system and accounts for the underlying L(L) roots that surface as HL in some constructions. A close look at Table 2 reveals that HTS occurs in all the tenses in at least one type of construction. Consider the following data with their underlying forms for illustration.

(14) a. Búgá jî zì kà bájn

Bún ó jì zí kò.bájn

Bung SM P2 eat C7.fufu

'Bung ate fufu.'

c. Búyá nlímsà lí kàbájn

Bún á n-lìmsà lí kò.bájn

Bung SMN-heat P4 C7.fufu

'Bung heated fufu.' b. Búyá kúmà lí kàbájn

Bún ó kùm lí kà.bájn

Bung SMtouch P1 C7.fuf

'Bung has touched fufu.'

d. 3í kálbájn

zí kà.bájn

eat IMP C7.fufu

'Eat fufu!'

HTS occurs from the SM to the tense marker in (14a), from the SM to the verb root in (14b and c), and from the verb root to the noun prefix in (a). HTS creates a contour tone on the tense marker in (a) but not in the rest of the contexts. In (b and c) it is followed by the delinking of the root low tone. The delinked tone merges with the schwa of the second syllable roots (c) while in (b), a schwa is inserted to bear the delinked root tone, as discussed in section (4.5). HTS to the noun prefix is blocked in (b and c) by the floating low tone of P1 and P4. In (a) the underlying high tone of the verb root is delinked, following Low Tone Spread discussed below in section 4.4. Due to schwa insertion in (b) both one-syllable and two-syllable low tone roots surface with an identical HL melody on two syllables, thereby neutralising the distinction between the two syllable types of verbs in this context. High Tone Spread is formalized as follows:

High Tone Spread

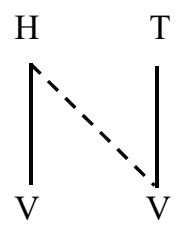

According to this rule an associated high tone spreads to the tone bearing unit to its right. HTS can be followed by other rules as described above and illustrated in the following derivation. 
(16)

\begin{tabular}{|c|c|c|}
\hline & $\begin{array}{l}\text { Búná nlímsà lí kàbájn } \\
\text { /Búy á N-lìmsà lí kàbájn }\end{array}$ & $\begin{array}{l}\text { Búyá jî ż̀ ká bájn } \\
\text { Búy ó jì ź́ kàbájn/ }\end{array}$ \\
\hline & 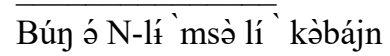 & 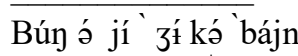 \\
\hline 1 & Búy á n-límsà lí kàbájn & Bún ó jî zì kátbájn \\
\hline & [Búyá nlímsà lí kàbájn & Búgá jî zì kábájjn] \\
\hline
\end{tabular}

Notice in Table 2 that past progressive forms do not undergo HTS, mainly because the SM from where HTS originates is not $\operatorname{present}^{8}(\mathrm{P} 2$, and P3) or rather has a low tone (P4). In P2 and $\mathrm{P} 3$, the SM does not occur when the subject is from classes 1, 6a, and 9. In P4, the schwa is retained but surprisingly it carries a low tone. This is probably due to the fact that classes $1,6 \mathrm{a}$, and 9 typically utilize low tones to mark agreement in Babanki, as in the associative construction (Akumbu 2011). How this is related to past progressive constructions remains unclear and requires further investigation.

5.4. Low tone spread (LTS). Low tone spread occurs in $\mathrm{P} 2$ and $\mathrm{P} 3$ affirmative constructions as well as in all past tense negative forms where the low tone that precedes the verb root spreads to and delinks the high tone of the verb or merges with the verb low tone. In P4 negative forms in Table 2, LTS originates from the floating low tone of the negation marker while in the rest of the constructions it is from the tense marker. The following data illustrate this process.

(17)a. Búyá jî ż̀ ká bájn

Bún á jì zí kà.bájn

Bung SMP2 eat C7.fufu

'Bung ate fufu.'

b. Búgá tâ làm kà bájn

Bún á tò lám kò.bájn

Bung SM P3 cook C7.fufu

'Bung cooked fufu?'

c. Búgá kô ż̀ kálbájn (bwén)

Bún á kó zí kà.bájn bwen

Bung SMNEG eat C7.fufu NEG

'Bung has not eaten fufu.'

d. Búyá kô jì sàytá kàbájn (bwén)

$\begin{array}{lllll}\text { Bún ó kó } & \text { jì sóntó kà.bájn } & \text { bwen } \\ \text { Bung SMNEG } & \text { P2 } & \text { sift } & \text { C7.fufu } & \text { NEG } \\ \text { 'Bung didn’t sift fufu' } & & \end{array}$

8 The subject marker (SM) changes depending on the noun class of the noun it represents. It is the same (z) for classes $1,2,3,5,6,6 \mathrm{a}, 8$, and 9 but ká ' $\mathrm{C} 7$ ', sá ' $\mathrm{C} 10$ ', tá ' $\mathrm{C} 13$ ', and fá ' $\mathrm{C} 19$ '. 
e. Búyá kô tà làm ká bájn (bwén)

Bún á kó tò lám kà.bájn bwen

Bung SM NEG P3 cook C7.fufu NEG

'Bung didn't cook fufu.'

f. Búyá kô nzì kà bájn (bwćn)

Bún á kó N-zá kò.bájn bwen

Bung SMNEG N-eat C7.fufu NEG

'Bung didn't eat fufu.'

The data show that underlying $\mathrm{H}(\mathrm{H})$ tone verb roots surface as $\mathrm{L}(\mathrm{H})$ due to LTS formalized as follows.

(18) Low Tone Spread

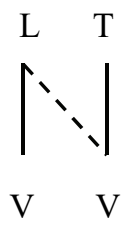

According to this rule an associated low tone spreads to the tone bearing unit to its right. LTS can be followed by other rules as illustrated in the following derivation.

Input

TD

LTS and delinking

HTS/docking \& delinking

Other rules

PR

\section{Búyá jî ż̀ kálbájn Búgá kô nzì kả bájn (bwén)}

/Bún á jì zá kò.bájn Bún á kó ’ N-zá kà.bájn bwen/

Bún á kô N-ź́ kà.bájn bwen

Búy á jì zì̀ kàbájn Bún á kô N-zì̀ kàbájn bwen

Bún á jî zì ká ’bájn

Bún ó jî ż̀ kálbájn

Bún á kô N-ż̀ ká ’bájn bwen

Bún á kô n-ż̀ kà bájn bwén

[Búná jî zì ká bájn

Búyá kô nzì kà bájn bwén]

One wonders why rising tones sometimes survive in the language and sometimes do not. Recall that a Low root followed by a High floating tone gives LH (e.g. kùmá ká bájn 'touch fufu') but a verb like $z^{\prime}$ 'eat' undergoes LTS and instead of keeping the LH, it rather simplifies to L, with the $\mathrm{H}$ being realized on the prefix of the following noun when an object follows. In addition, the way the tone of the object is affected depends on the underlying tone pattern of the noun (Hyman 1979:162).

(20)a. Búyá jî yà? kákj̀s

Bún á jì yá? kò.kòs

Bung SM P2 catch C7.slave

'Bung caught a slave.' b. BúĐá jî yà? kà bájn

$\begin{array}{llll}\text { Bún à jì yá? } & \text { k̀̀.bájn } \\ \text { Bung SMP2 catch } & \text { C7.fufu } \\ \text { 'Bung caught fufu.' }\end{array}$


c. Búyá jî yà? dzêm

Bún á jì yá? dzغ̀m ${ }^{\circ}$

Bung SMP2 catch C9.back

'Bung caught a back.'

e. Búyá jî yà? nàm

Bún á jì yá? jàm

Bung SMP2 catch C9.animal

'Bung caught an animal.'

g. Búyá jî yà? mútú

Bún ó jì yá? mútú

Bung SMP2 catch C6a.water

'Bung caught water.' d. Búyá jî yà? kàmbò

Bún ó jì yá? kว̀.mbòo

Bung SMP2 catch C7.bag

'Bung caught a bag.'

f. Búyá jî yà? bú

Bún ó jì yá? bú

Bung SMP2 catch C9.dog

'Bung caught a dog.'

The data show that after LTS the high tone from the verb affects the tone of the object in different ways as follows: underlying L-L nouns are realized as $\mathrm{H}-\mathrm{L}(\mathrm{a}), \mathrm{L}-\mathrm{H}$ as $\mathrm{H}^{\downarrow} \mathrm{H}$ (b), and $\mathrm{L}^{09}$ as HL (c), while the rest do not change.

It should also be mentioned that pronouns and prepositional phrases that follow the verb can also be affected in various ways, as shown in the data below.

(21)a. Búyá jî̀ yà? wù

Bún á jì yá? wù

Bung SMP2 catch 2s

'Bung caught you.'

c. Búgá jî yà? jés

Bún ó jì yá? jès

Bung SM P2 catch 1p

'Bung caught us.' b. Búyá jî yà? váwé

Búy á jì yá? vòwé

Bung SMP2 catch $3 p$

'Bung caught them.'

d. Búyá jî yà? á Đgày

Búy á jì yá? á ygàn

Bung SMP2 catch PREP c9.house

'Bung caught in the house.'

e. Búná jî yà? nà kàvú ká wén

Bún á jì yá? nò kà.vú ká wén

Bung SMP2 catch PREP c7.hand AM 3s

'Bung caught with his hand.'

The delinked high tone of the verb surfaces on the first syllable of two-syllable pronouns (b and c) but not on one-syllable low tone pronouns (a) or preposition (e). Interestingly, LTS fails to apply if nothing follows the verb.

\footnotetext{
${ }^{9}$ The small 'o' after ' $\mathrm{L}$ ' indicates that the low tone is floating.
} 
(22)a. Búyá jî zí

Bún ó jì zí

Bung SMP2 eat

'Bung ate.' b. Búyá tâ lám

Bún ó tò lám

Bung SMP3 cook

'Bung cooked.'

c. Búyá kô zí

Bún á kó zú

Bung SM NEG eat

'Bung has not eaten.'

5.5 Schwa Insertion (SI). It has already been mentioned that a schwa can be inserted to bear certain tones such as the floating imperative tone (sections 4.2 and 4.3). The insertion of this midcentral low vowel whenever the need for a vowel arises is possible evidence that the schwa is the default vowel in Babanki. The following examples show schwa insertion.
(23)a. lèá kà bájn
lè kò.bájn
lose IMP C7.fufu
'Lose fufu!'

c. Búyá lámá kàbájn

Bún á lám k’̀̀.bájn

Bung SMcook PROG C7.fufu

'Bung is cooking fufu.' b. Búyá kúmà lí kàbáj

Bún ó kùm lí kà.bájn

Bung SM touch P1 C7.fufu

'Bung has touched fufu.'

d. Búyá kùmà kàbájn

Búy á kùm kà.bájn
Bung SM touch PROG C7.fufu
'Bung is touching fufu,'

'Bung is touching fufu.'

\section{e. Búyá sáytà kàbájn}

Bún ó sóntá ' kà.bájn
Bung SM sift PROG C7.fufu
'Bung is sifting fufu.'

The schwa is inserted in (a) to bear the high tone of the imperative. In (b) it is inserted to bear the delinked low tone that results from HTS from the SM to the verb root and subsequent deletion of that verb tone. In (c and d) schwa insertion is required so that it can bear the low tone of the progressive (PROG) marker. PROG is marked by a floating low tone which is found after the verb root. This is contrary to Akumbu \& Fogwe (2012) who claim that PROG is marked by a toneless schwa. Instead, the schwa bears a high tone in (c), due to HTS from the verb root that results in the delinking of the progressive low tone. Interestingly two-syllable high tone roots that end in a schwa (e) are affected differently as the second high tone is replaced by the low tone of the progressive. For this reason some HH verb roots surface as HL.

Schwa insertion could suggest that historically Babanki verb roots were disyllablic and the final syllable has been lost over time. The schwa is therefore a trace of that final vowel which is realized only under some conditions. Further evidence for disyllablic roots in Babanki comes from plural subject pronouns where traces of two or three syllables still survive in such alternations as: 


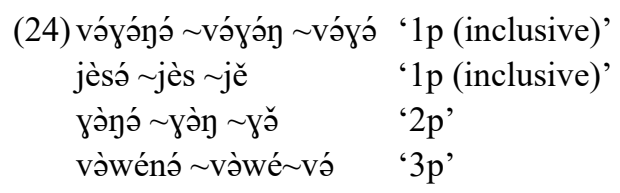

Each of the pronouns can be used in any of the three ways with the general tendency being to use the most simplified version except where there are restrictions. The presence of the schwa on the second or third syllable provides justification for schwa insertion.

\section{Verb reduplication tone}

The way tones behave when verbs are reduplicated depends on the verb group. Sometimes within the same group, reduplication patterns differently depending on the syllable structure of the verb.

6.1. High tone verbs. High tone verbs exhibit both total (morphological completeness) and partial (tonal difference) reduplication. In the following table one-syllable high tone verbs are shown in their base and reduplicated forms.

Table 3: One-syllable high tone root reduplication

\begin{tabular}{|c|c|c|c|c|c|}
\hline Infinitive & $\begin{array}{l}\text { Reduplicated } \\
\text { Infinitive }\end{array}$ & Imperative & $\begin{array}{l}\text { Reduplicated } \\
\text { Imperative }\end{array}$ & $\begin{array}{l}\text { Reduplicated } \\
\text { progressive }\end{array}$ & gloss \\
\hline á- $\downarrow_{\text {té }}$ & ó-tété & té & tétéá & téá téá & 'insult' \\
\hline á-`bwí & á- ${ }^{\downarrow}$ bwíbwí & bwí & bwíbwíá & bwíábwíá & 'give birth' \\
\hline à-záf & á- záfzáfó & záf & záfzáfá & záfă ${ }^{\downarrow}$ záfá & 'ache' \\
\hline ó-`zím & ว́- 'zímzímá & 3ím & 3ímzímó & zímá zímá & 'sing' \\
\hline á- bwóm & á- ${ }^{\downarrow}$ bwómbwómá & bwóm & bwómbwómว́ & bwómá bwómá & 'build' \\
\hline
\end{tabular}

Downstepping of the high tone in the infinitive forms results in the second high tone being lower than the first (see §5.1). Reduplication of the imperative forms shows that there is a high tone reduplicant (RED) ${ }^{10}$ morpheme (a) that is added at the end of the reduplicated form (see especially the reduplicated CVC roots). It also shows that the tones and segments of the base are identical to those of the RED. In the reduplicated progressive forms the RED morpheme surfaces on the RED and a schwa is inserted after the base to bear the progressive low tone. The progressive tone is eventually replaced by the high tone of the root as described in $§ 5.5$. Downstep of the RED tone is caused by the progressive low tone that floats after the application of HTS as illustrated in the following RTT derivation.

${ }^{10}$ The reduplicant is an affix onto which features or segments of the morphological base are copied while the base refers to the verb or part of it that is to be copied. 
Figure 5: Downstep in reduplicated forms

Input

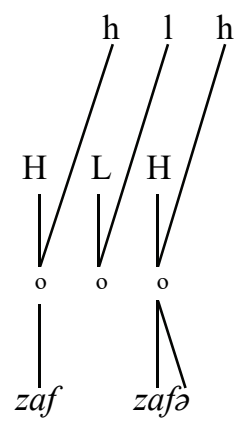

HTS and Low Tone Delink

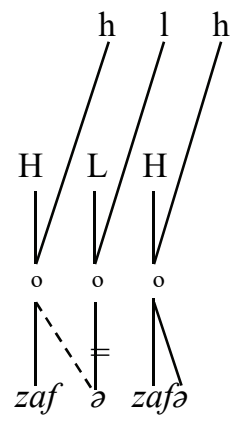

Stray Erasure and Merger

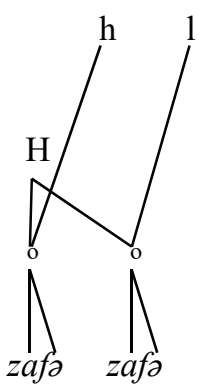

Schwa Insertion and Low Tone Docking

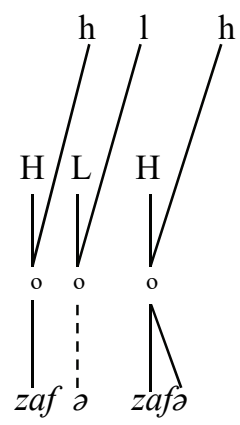

Downstep

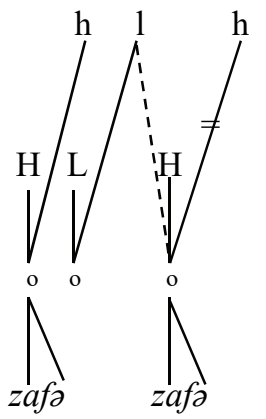

Phonetic Representation

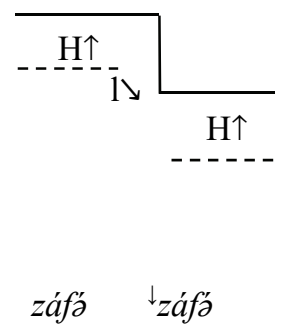

The derivation shows that the first high tone is realized on a high register and the second on a low register. Next, consider the two-syllable high tone verbs in Table 4. 
Table 4: Two-syllable high tone root reduplication

\begin{tabular}{|c|c|c|c|c|c|}
\hline Infinitive & $\begin{array}{l}\text { Reduplicated } \\
\text { Infinitive }\end{array}$ & Imperative & $\begin{array}{l}\text { Reduplicated } \\
\text { Imperative }\end{array}$ & $\begin{array}{l}\text { Reduplicated } \\
\text { progressive }\end{array}$ & gloss \\
\hline ó- ${ }^{\downarrow}$ sáyló & ว́-`sáylásánlá & sánló & sáylósáyló & sáylòsàyló & 'rejoice' \\
\hline ó-bá?tó & ó-`báPtábá?tó & bá?tó & báPtóbá?tó & báPtə̀bà?tá & 'gather' \\
\hline ó- ttímá & ว́- 'tímótímó & tímó & t'́mótt́mó & tímòtt̀má & 'stand' \\
\hline ó- 'búnkó & ó-búnkóbúnkó & búykó & búykábúykó & búykàbùyká & 'roll' \\
\hline 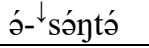 & ว́- $\downarrow$ sántว́sántá & sóntó & sáytásóntó & sə́ytว̀sə̀ytá & 'sift' \\
\hline
\end{tabular}

These data further illustrate what happens with one-syllable high tone verbs in forms other than the reduplicated progressive. In these progressive forms, the last tone of the base is low as expected after progressive low tone docking and high tone delinking apply (§5.5). However, the first syllable of the RED unpredictably surfaces as low instead of high. To explain this it has been assumed that the derived low tone of the base spreads rightward and delinks the first high tone of the $\mathrm{RED}^{11}$, as shown in the following derivation.

Figure 6: Low Tone Spread in reduplicated forms

Input

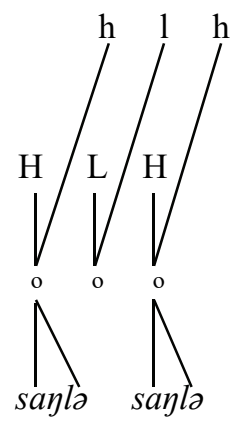

Tone Docking and High Tone Delink
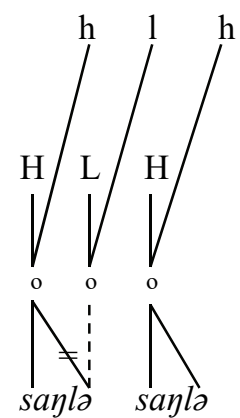

Low Tone Spread and High Tone Delink

Stray Erasure
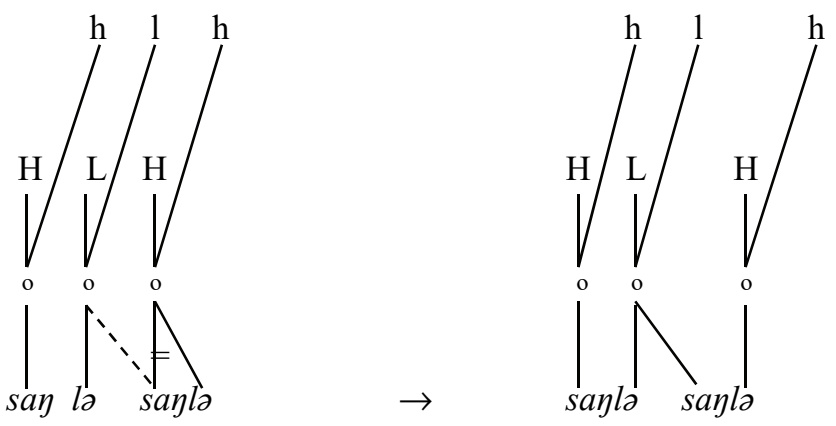

${ }^{11}$ This isolated process requires further investigation as it has been found to occur only in the context of the reduplication of two syllable high tone verbs in the progressive. 
(Figure 6 cont.)

Phonetic Representation

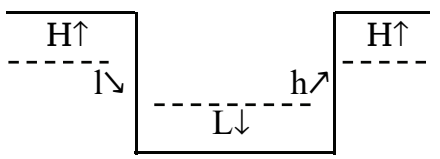

sáy là sàn lá

The first syllable has a high tone realized on a high register while the second and third syllables have a low tone realized on a low register. The register is again shifted upward for the last syllable and the high tone is realized on a high register.

6.2. Low tone verbs. Low tone verbs exhibit only partial reduplication such that segments in the base and reduplicant manifest tonal differences. The reduplication pattern on both one- and twosyllable low tone verbs is shown in the next table. They are put together because tone behaves in a similar manner regardless of the syllable type.

Table 5: Low tone root reduplication

\begin{tabular}{|c|c|c|c|c|c|}
\hline Infinitive & $\begin{array}{l}\text { Reduplicated } \\
\text { Infinitive }\end{array}$ & Imperative & $\begin{array}{l}\text { Reduplicated } \\
\text { Imperative }\end{array}$ & $\begin{array}{l}\text { Reduplicated } \\
\text { progressive }\end{array}$ & gloss \\
\hline ว́-t $\int 0 ̀$ & 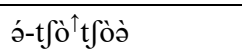 & 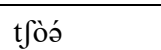 & 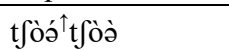 & t & 'pass' \\
\hline á-vì & ว́-vì vì̀ & vìa & vìâvì̀ & vì๋̀ vì̀ & 'come' \\
\hline á-swè & ó-swè swè̀ & swèá & swèá ${ }^{\uparrow}$ swè & swèò swè̀̀ & 'miss' \\
\hline ó-kùm & á-kùm ${ }^{\uparrow}$ kùmò & kùmó & kùmó ${ }^{\uparrow}$ kùmò & kùmò kùmว̀ & 'touch' \\
\hline ว́-mwòm & 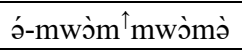 & mwòmá & mwòmá & mwòmà mwòmว̀ & 'taste' \\
\hline á-kùmtà & á-kùmtว̀ kùmtว̀ & kùmtá & kùmtá ${ }^{\uparrow}$ kùmtว̀ & kùmtà kùmtò & 'reiterate' \\
\hline á-bìlà & á-bìlà bùlà & bìlá & bìlấbìlà & bìlà bìlà & 'alter' \\
\hline ว́-sìsà & ว́-sìsà sìsà & sìsá & sìsá ${ }^{\uparrow}$ sìsà & sìsà sìsà & 'refund' \\
\hline á-kàylà & á-kànlà kàylà & kàylá & kàylá kànlà & kàylà kàylà & 'stagger' \\
\hline á-tànkj̀ & á-tàykà tàykว̀ & tàyká & tàykấtànkò & tànkà tànkò & 'try' \\
\hline á-nà?sà & ว́-nàPsà̂nà?sà & nà?sá & nà?sá nà?sà & nà?sạ̀nà?sà & 'stretch' \\
\hline
\end{tabular}

An observation to be made from the table is that the low tone on the RED is upstepped in all instances of reduplication involving low tone roots. The upstepped low tone is like a mid tone, higher than a low tone but lower than a high tone and both low tones following the point of upstep are realized at that same mid level. Upstep is the effect of the RED high tone that fails to surface in the context of low tones. Recall that when high tone roots are reduplicated, a high tone schwa is found at the end of the RED. In the case of low tone roots the presence of that high tone is only realized through the upstepping of the low tones of the RED. This is certainly a phonetic effect of anticipating the presence of the high tone and realizing the low tone on a high register. For this to happen the high register feature of the RED high tone spreads leftward and delinks the low register feature of the RED low tone. Upstep is formalized in RTT terms as follows. 
(25) Upstep (in low tone reduplicants)

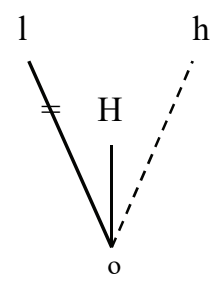

An application of this rule leads to the upstep of low tones of the reduplicant, as shown in the derivation that follows.

Figure 7: Upstep

Input

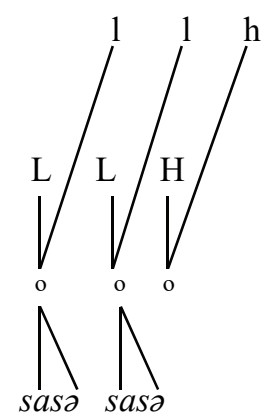

Upstep and Stray Erasure

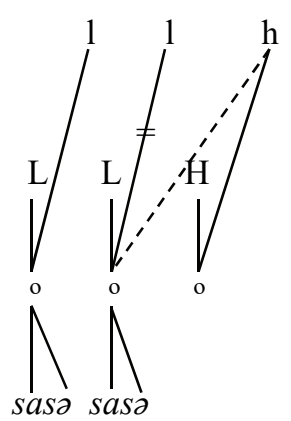

Phonetic Representation

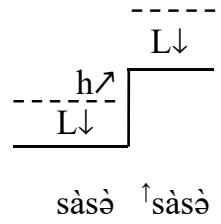

The first low tone is realized on a low register and the second on a high register due to the upward shift in register caused by leftward $h$ register spreading and $l$ register delinking.

The imperative forms in Table 5 are regular in that the imperative high tone surfaces on an inserted schwa on one-syllable roots and replaces the low tone of the second syllable in twosyllable roots, as described in $§ 5.2$.

\section{Conclusion}

This paper set out to account for the different surface tonal melodies found on Babanki verbs. In order to accomplish this task, each phonological process that affects the verb system has been discussed. In this regard it has been shown that tone spread is frequent in the language. HTS can be to the verb root or from it and has been used to explain why underlying low tone roots surface with $\mathrm{HL}$ and $\mathrm{H}(\mathrm{H})$ melodies. LTS can also be from a preceding tense marker to the verb root or 
from the verb root, followed by the delinking of the underlying high tone. This process has been used to account for the occurrence of $\mathrm{L}(\mathrm{H})$ melodies on underlying high tone verb roots. It has also been observed that a schwa is inserted in many instances to bear a floating tone. It is due to schwa insertion and tone docking that the $\mathrm{HH}$ melody is realized as HL. Verbal reduplication is common in the language and equally undergoes the processes described above in addition to low tone upstep that low tone reduplicants undergo.

The use of floating tones to account for tone in the Babanki verb system is in no way surprising in that previous researchers have shown that both lexical and grammatical floating tones are central to the analysis of Grassfields Bantu languages. In this regard Hyman notes,

To account for tone in other Grassfields Bantu languages, it has been proposed that each stem consists of an underlying segmental tone ( $\mathrm{H}$ or $\mathrm{L})$, followed by a nonsegmental or floating tone (also either H or L) (Hyman 1979: 159).

Although their conditions and manner of application may differ, the rules proposed in this paper to account for the verb tone relate to previous rules that apply in the noun system. Both Hyman (1979) and Akumbu (2011) recognize and use HTS, LTS, Downstep, and Upstep, among others to account for tone in the associative construction. It can therefore be concluded that the rules proposed in this paper are plausible and frequently attested in Babanki.

This study complements work on tone in the noun system of Babanki and together they offer a full picture of the tone system of the language. This study also shows that Register Tier Theory allows for an insightful account of assimilation processes, downstep, and upstep which occur in Babanki. Similar studies on the other Centre Ring languages are necessary to provide a complete understanding of their tonal systems and facilitate the reconstruction of Proto-Bantoid tone. 


\section{References}

Achiri-Taboh, Blasius. 2013. Verb imperatives and vowel harmony in Moghamo. Ms, University of Buea.

Akumbu, Pius. 2011. Tone in Kejom (Babanki) associative construction. Journal of West African Languages. Volume 38, No 1: 69-88.

Akumbu, Pius \& Fogwe, Evelyn. 2012. A pedagogic grammar of Babanki. Köln: Rüdiger Köppe Verlag.

Connell, Bruce. 2001. Downdrift, downstep, and declination. Paper presented at the Typology of African Prosodic Systems Workshop. Bielefeld University, Germany, May 18-20, 2001.

Hyman, Larry. 2013. Proto-Bantoid verb extensions. Paper presented at the Workshop on Bantu and its Closest Relatives, Berlin Bantu Conference (B4ntu), April 6-9, 2011.

Hyman, Larry. 1980. Babanki and the Ring group. In L. Hyman and J. Voorhoeve, (eds.), Noun Classes in Grassfields (225-258). Paris: SELAF.

Hyman, Larry. 1979. Tonology of the Babanki noun. Studies in African Linguistics 10.159-178.

Inkelas, Sharon. 1987. Tone feature geometry. In J. Blevins and J. Carter (eds.). Proceedings of North Eastern Linguistics Society 18, 223-37. Amherst, Mass: GLSA.

Inkelas, Sharon, W. Leben and M. Cobler. 1987. The phonology of intonation in Hausa. In

J. Blevins and J. Carter (eds.). Proceedings of North Eastern Linguistics Society 17, 327-42. Amherst, Mass: GLSA.

Lewis, M. Paul, Gary F. Simons, and Charles D. Fennig (eds.). 2015. Ethnologue: Languages of the World, Eighteenth edition. Dallas, Texas: SIL International. Online version: http://www.ethnologue.com.

Nurse, Derek. 2003. Aspect and tense in Bantu languages. In D. Nurse, and G. Philippson, (eds.), The Bantu languages. New York: Routledge, 90-102.

Shultz, George. 1997. Kom language grammar sketch, Part 1. Yaounde: SIL.

Snider, Keith L. 1988. Towards the representation of tone: a three-dimensional approach. In Harry Van de Hulst and Norval Smith (eds.). Features, segmental structure and harmony processes (Part 1), 237-65. Dordrecht: Foris Publications.

Snider, Keith L. 1990. Tonal upstep in Krachi: Evidence for a register tier. Language 66.3, 453-74.

Snider, Keith L. 1999. The geometry and features of tone. Dallas: The Summer Institute of Linguistics and The University of Texas at Arlington.

Tamanji, Pius. 2009. A descriptive grammar of Bafut. Cologne: Rüdiger Köppe Verlag.

Pius W. Akumbu

University of Buea, Cameroon akumbu.pius@ubuea.cm
Received: 9 Mar 14

Accepted: 6 Feb 15

Corrections: 24 July 2015 